\title{
The rise of China: to whom is it scary?
}

\author{
Jung Taik Hyun ${ }^{*}$ and Moon Joong Tcha**
}

\begin{abstract}
China has been the most important economic partner to Korea since the resurrection of their diplomatic relationship and economic interaction. It has been suggested that China simultaneously presents challenges and opportunities to the Korean economy. This paper investigates changes in trade specialization patterns and comparative advantage of Korea and China, and analyzes the effect of market expansion of Chinese industries on market shares of Korean industries. It is found that since the early 1990s, the industries that lost market share as China's share increased include those in which Korea has maintained a comparative advantage or improved the level of disadvantage, such as IT equipment and other transport equipments. Considering growth of trade flows and emergence of China, it is critical for Korea to actively participate in international production chains, create competitive edges and extend complementary relationship with trading partners.
\end{abstract}

Keywords: Korea's exports, RCA, China effects, Industrial structure, Market shares.

\section{Introduction}

While each and every stage of the development process of the Korean economy since the early 1960s has been dramatic, the nation's survival of economic crisis and the resurrection from it in the late 1990s may be the highlight of the recent history. The 1990s was a period of storm and stress for the Korean economy. Though the economy faced various challenges, it broke through the US $\$ 10,000$ GDP per capita, and became an OECD member country, but shortly after, the country was engulfed in a crisis. 
The Korean economy recorded remarkable growth up until 1997, however, Kim (2001) and Kwack (2001) point out that the economy in fact had lost its competitiveness gradually edging towards the outbreak of the economic crisis. Costs including material costs, labor costs, and borrowing costs had been consistently increasing since the 1990s, which was accompanied by a substantial increase in the unit value of exporting goods until the dawn of the economic crisis (Tcha and Lee, 2003). KDI's (2003) study on the competitiveness of the Korean industries also revealed that total productivity of Korean industries during the first half of the 1990s fell short of that before and after the period.

Together with an economic crisis, a most critical change that the Korean economy had to face during this period was the emergence of China. As pointed out by Gaulier, Lemoine and UnalKesenci (2006), the emergence of China reorganized the entire trade flows in Asia, and as well known, it also contributed to the growth of the Korean economy, providing a large market for Korean producers. However, at the same time, it became a competitor of Korea in the world market for a variety of products (for example, Hyun, 2006). This paper investigates the Korean economy during this period, in particular, concentrating on changes in certain aspects of trade, and considering China as one of the most important factors affecting Korea's export performance. The major aim of this paper is to investigate structural changes in trade patterns of Korea and China, and analyze how the market share of Korea in the world for selected manufacturing industries have been affected by the emergence of China.

This paper consists of four sections. Section II discusses structural changes in trade of the two countries in the 1990s and the 2000s. Revealed comparative advantage (RCA) indices developed by Centre d'Etudes Prospectives et d'Information Internationales (CEPII) are calculated for each industry to find structural changes in relative advantage of the nations. The findings from this study will provide more accurate and updated information than those from Choi, Tcha and Kim (2005). Section III analyzes the effect of the emergence of China on the performance of Korean industries in the major markets, using quantitative approach. The paper concludes with Section IV.

\section{Comparisons of trade structures - Korea and China}

\subsection{Changes in the structure of trade ${ }^{1}$}

\section{Exports by destination}

For fourteen years since 1992, the Korean manufacturing sector increased its exports to the world substantially, as summarized in Table 1 . The fastest growing market for Korea during the period was China. While Korea's export of manufacturing goods to the world increased $10 \%$ on annual average, those to China recorded an annual growth of about $25 \%$. This performance is

\footnotetext{
${ }^{1}$ All the trade data used in this section are in the form of SITC, KSIC and HS. Codes are matched according to the $\mathrm{KDI}$ system for the general analysis.
} 
much higher than that to Japan or the US where annual growth rate of Korea's manufacturing exports recorded $4 \%$ and $6 \%$, respectively. For the period, EU was the second fastest growing market; however, the annual growth rate of $9 \%$ was much lower than that for the Chinese market.

The leading industries that show very rapid increase in exports to the world include precision instrument (annual growth of 23\%), automobiles (18\%), general machinery (14\%), IT equipment $(12 \%)$, electronics \& parts $(12 \%)$ and other transport equipment $(12 \%)$. In contrast, textile \& clothes $(-0.03 \%)$, food products \& beverage $(-0.02 \%)$, and petroleum \& coal $(-0.08 \%)$ industries show negative growth. While no industry shows negative growth for Korea's exports to China, such industries as semiconductors (annual growth of 73\%) and precision instruments $(65 \%)$ demonstrated remarkable penetration into the Chinese market. Exports of automobiles (45\%) and IT equipment (44\%), home appliances (31\%), and electronics \& parts (30\%) also show a very high rate of growth.

The industries that successfully expanded their markets in China can be drawn out more clearly when the growth rate of Korea's exports to China is compared to that to the world. Paper products, printing \& publishing and other transport equipments are the two industries where Korea's export growth to China was slower than that to the world. For all electric and electronic industries including semiconductors, electronics \& parts, IT equipment and home appliances, the growth rate of Korea's exports to China was higher than that to the world.

Table 1

Annual average growth rate of Korea's exports (1992-2006)

\begin{tabular}{l|c|c|c|c|c|c}
\hline & \multicolumn{7}{|c}{ Korea to } \\
\cline { 2 - 7 } & US & China & Japan & ASEAN & EU7 & World \\
\hline \hline \multirow{3}{*}{ Food \& Beverage } & 0.03 & 0.26 & -0.06 & 0.03 & -0.08 & -0.02 \\
Textiles \& Clothes & $(-1.21)$ & $(-11.6)$ & $(2.84)$ & $(-1.14)$ & $(3.75)$ & $(1.00)$ \\
& -0.07 & 0.14 & -0.11 & 0.02 & -0.09 & -0.03 \\
Paper Products, Printing, Publishing & $(2.24)$ & $(-4.39)$ & $(3.33)$ & $(-0.68)$ & $(2.68)$ & $(1.00)$ \\
& 0.15 & 0.09 & 0.15 & 0.13 & 0.08 & 0.11 \\
Chemical Products & $(1.37)$ & $(0.83)$ & $(1.39)$ & $(1.17)$ & $(0.77)$ & $(1.00)$ \\
& 0.09 & 0.24 & 0.10 & 0.08 & 0.09 & 0.13 \\
Petroleum \& Coal Products & $(0.69)$ & $(1.93)$ & $(0.79)$ & $(0.66)$ & $(0.69)$ & $(1.00)$ \\
Non-metallic Mineral Products & -0.28 & 0.12 & -0.15 & -0.24 & 0.03 & -0.08 \\
& $(3.27)$ & $(-1.39)$ & $(1.82)$ & $(2.86)$ & $(-0.30)$ & $(1.00)$ \\
Basic Metals & 0.09 & 0.28 & -0.04 & 0.06 & 0.12 & 0.06 \\
& $(1.36)$ & $(4.44)$ & $(-0.57)$ & $(0.91)$ & $(1.95)$ & $(1.00)$ \\
Metals & 0.07 & 0.14 & 0.02 & 0.11 & 0.15 & 0.10 \\
& $(0.75)$ & $(1.38)$ & $(0.24)$ & $(1.11)$ & $(1.53)$ & $(1.00)$ \\
& 0.04 & 0.18 & 0.10 & 0.05 & 0.05 & 0.07 \\
& $(0.51)$ & $(2.39)$ & $(1.33)$ & $(0.73)$ & $(0.67)$ & $(1.00)$ \\
\hline
\end{tabular}




\begin{tabular}{l|c|c|c|c|c|c}
\hline \multirow{4}{*}{ General Machinery } & 0.09 & 0.28 & 0.14 & 0.07 & 0.16 & 0.14 \\
& $(0.63)$ & $(1.97)$ & $(0.96)$ & $(0.49)$ & $(1.11)$ & $(1.00)$ \\
Semiconductors & -0.01 & 0.73 & 0.11 & -0.33 & 0.07 & 0.11 \\
Electronics \& Parts & $(-0.07)$ & $(6.38)$ & $(0.98)$ & $(-2.92)$ & $(0.61)$ & $(1.00)$ \\
& 0.09 & 0.30 & 0.10 & 0.11 & 0.11 & 0.12 \\
IT Equipment & $(0.70)$ & $(2.46)$ & $(0.79)$ & $(0.88)$ & $(0.92)$ & $(1.00)$ \\
Home Appliances & 0.06 & 0.44 & 0.06 & 0.13 & 0.10 & 0.12 \\
& $(0.51)$ & $(3.54)$ & $(0.51)$ & $(1.04)$ & $(0.81)$ & $(1.00)$ \\
Automobiles & 0.10 & 0.31 & 0.09 & -0.01 & 0.08 & 0.08 \\
Other Transport Equipment & $(1.22)$ & $(3.84)$ & $(1.13)$ & $(-0.07)$ & $(1.02)$ & $(1.00)$ \\
& 0.16 & 0.45 & 0.09 & 0.18 & 0.18 & 0.18 \\
Precision Instruments & $(0.87)$ & $(2.51)$ & $(0.52)$ & $(0.98)$ & $(0.99)$ & $(1.00)$ \\
& 0.09 & 0.09 & 0.05 & 0.23 & 0.17 & 0.12 \\
Other Manufacturing & $(0.72)$ & $(0.71)$ & $(0.38)$ & $(1.88)$ & $(1.41)$ & $(1.00)$ \\
& 0.10 & 0.65 & 0.25 & 0.15 & 0.19 & 0.23 \\
Total Manufacturing & $(0.41)$ & $(2.83)$ & $(1.09)$ & $(0.65)$ & $(0.82)$ & $(1.00)$ \\
& -0.05 & 0.21 & -0.03 & 0.05 & -0.06 & -0.01 \\
& $(4.43)$ & $(-19.88)$ & $(2.74)$ & $(-4.90)$ & $(5.91)$ & $(1.00)$ \\
\hline
\end{tabular}

Note: Numbers in parentheses are the ratio of annual growth of each industry's exports to that of manufacturing exports to the world.

Source: UNCTAD (1992-2006)

For example, Korea's exports of semiconductors to China grew 6.38 times faster than that to the world for each year during the 14 years under investigation. Automobiles, general machinery and precision instruments also show two to three times higher growth rates in the Chinese market.

In contrast, the growth rates of Korea's exports to Japan in industries related to electric and electronics, machinery and automobile turn out to be lower than that to the world, indicating that it was still challenging for Korean industries to penetrate into these markets of Japan. This finding is consistent with Ko, Cho, Lee, Lee, and Lee (2003). Nevertheless, it should be pointed out that Korea's exports to the other developed regions such as the US and EU, in fact, increased rapidly in absolute terms, recording annual growth rates higher than 5\%. Annual average growth of Korea's exports to the US and EU recorded 6\% and 9\%, respectively. As a result, Korea's export share by destination for the period between 1992-2006 can be illustrated as Figure 1. It is clearly shown that China became the largest destination for Korea's exports since 2003, while the share of the US became lower. Shares of Japan and ASEAN also have been decreasing while that of EU has been stagnating. 


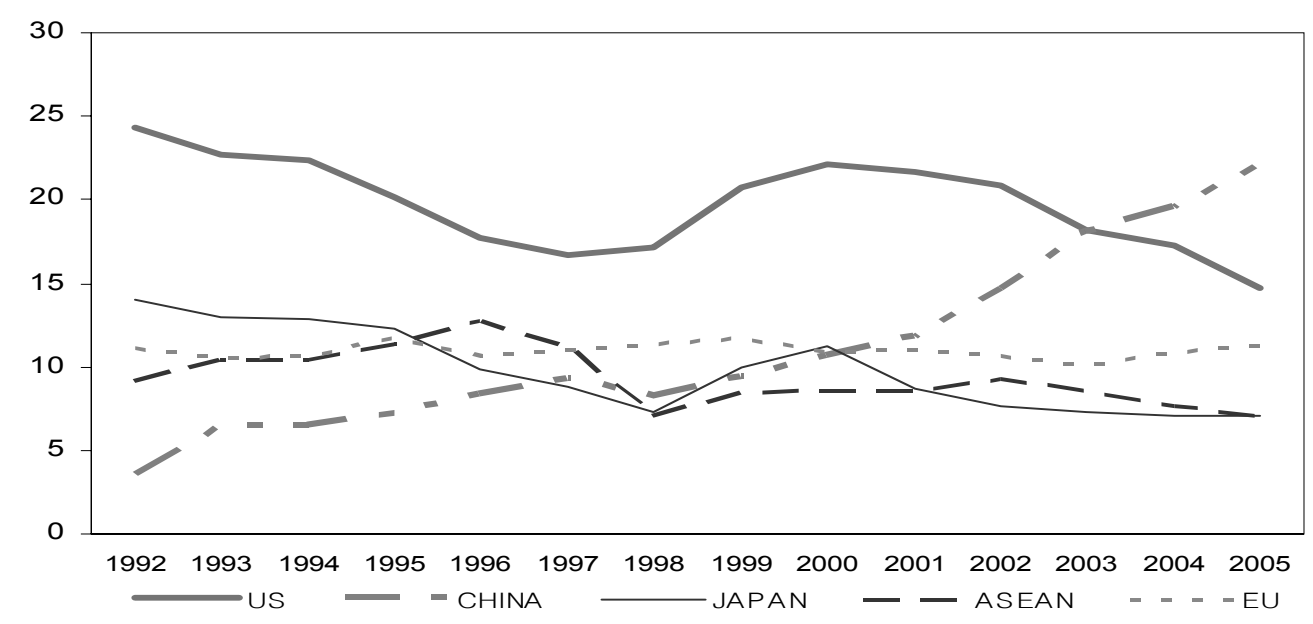

Figure 1. Korea's export share by destination (1992-2006)

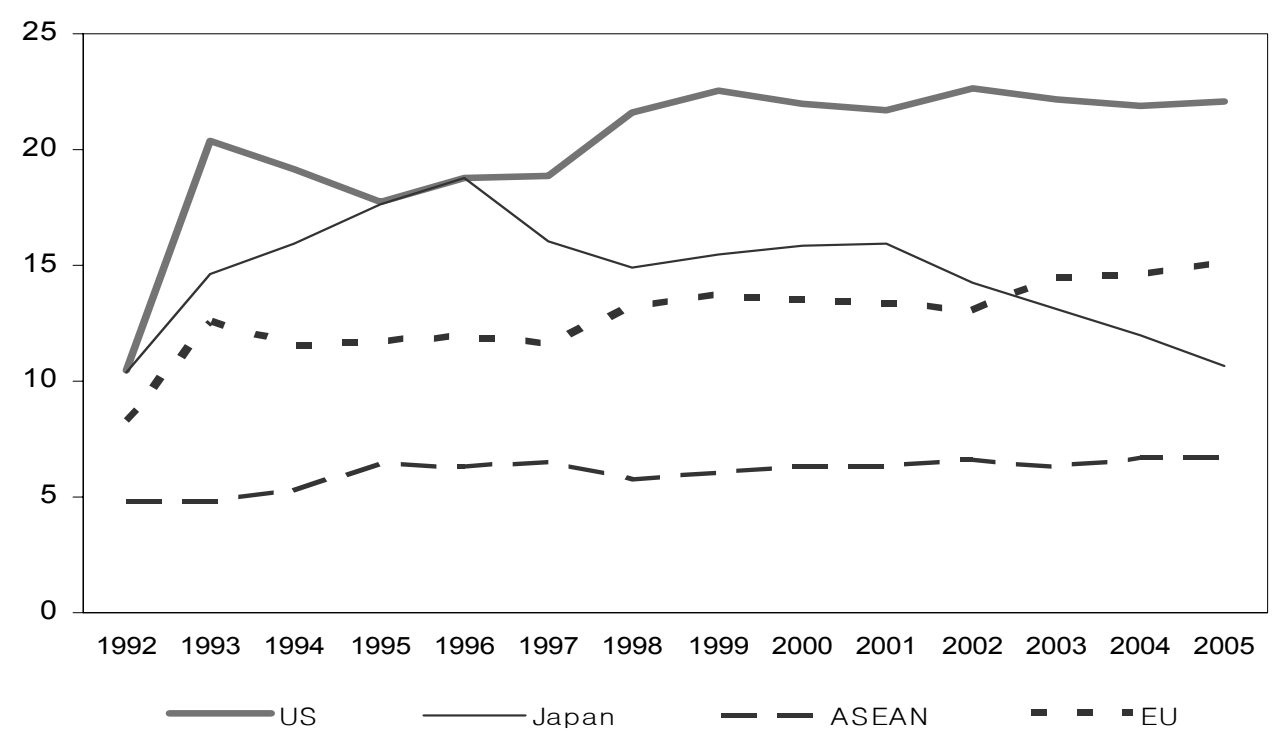

Note: EU does not include new members who joined since 1992. If we include them, EU becomes the second largest destination of Korea's exports in the 2000s.

Figure 2. China's export share by destination (1992-2006) 
This trend in Korea's exports shows a big contrast to the changes in China's export destinations. For China, while the importance of Japan as a destination has been declining, that of the US has been increasing, absorbing the largest parts of China's exports. Almost a quarter of China's exports to the world have been directed to the US in the 2000s. Export share of Japan reached about 20\%, almost the same level as the US, in 1996, and then it started to decrease in becoming a smaller market than EU to China.

\subsection{Export by industry}

Table 2 summarizes the changes in export shares of each industry for Korea and China for selected years. The most dramatic finding is the concentration of each country on certain items, and their changes over time. In the case of Korea in 1992, 25.9\% of manufacturing exports were explained by textile \& clothes industry. IT equipment $(12.6 \%)$, chemical products $(9.9 \%)$, semiconductors (8.9\%), and basic metals $(6.7 \%)$ also accounted for a significant portion of exports. Three largest exporters (textile \& clothes, IT equipment, and chemical industries) explained about a half of total exports (48.4\%). If we add the two next largest exporters such as semiconductors and basic metal industries, altogether they accounted for almost two thirds of total exports. However, fourteen years later in 2006, IT equipment, automobiles and chemical products became the largest export leaders, explained $17.2 \%, 14.9 \%$, and $13.9 \%$ of total exports, respectively. These three industries' exports took about $46.0 \%$ of the exports of total manufacturing. Semiconductors and other transport equipment such as ships or shipping followed these three industries.

This phenomenon is also found in China. In fact, the degree of concentration is even more magnified than Korea. In 1992, 37.8\% of China's manufacturing exports were from the textile \& clothing industry. The second largest was food \& beverage (12.3\%) followed by chemical products (7.4\%). The three largest export leaders explained 57.5\% of total manufacturing exports. Fourteen years later, the largest export of China changed to IT equipment, whose export share was $25.9 \%$. Textile \& clothes industry was still substantial, however, its share decreased to $20.1 \%$. This was followed by the chemical industry, of which export share reached $8.1 \%$. They accounted for $54.1 \%$ of total manufacturing exports from China. 
Table 2

Exports shares of Korea and China by industry

$(\%)$

\begin{tabular}{|c|c|c|c|c|c|c|}
\hline & \multicolumn{3}{|c|}{ Korea } & \multicolumn{3}{|c|}{ China } \\
\hline & 1992 & 1999 & 2006 & 1992 & 1999 & 2006 \\
\hline Food \& Beverage & 3.31 & 2.19 & 0.63 & 12.33 & 6.59 & 1.50 \\
\hline Textiles \& Clothes & 25.93 & 13.41 & 4.32 & 37.80 & 29.17 & 20.14 \\
\hline Paper Products, Printing, Publishing & 0.80 & 1.42 & 0.88 & 0.62 & 0.66 & 0.75 \\
\hline Chemical Products & 9.93 & 10.67 & 13.89 & 7.37 & 8.31 & 8.12 \\
\hline Petroleum \& Coal Product & 2.19 & 4.06 & 0.17 & 5.47 & 2.38 & 0.32 \\
\hline Non-metallic Mineral Products & 0.86 & 0.60 & 0.53 & 2.45 & 2.24 & 1.86 \\
\hline Basic Metals & 6.65 & 3.95 & 6.55 & 2.58 & 2.60 & 4.77 \\
\hline Metals & 3.06 & 4.34 & 2.20 & 3.26 & 3.61 & 3.86 \\
\hline General Machinery & 4.20 & 5.12 & 7.12 & 2.82 & 3.76 & 5.42 \\
\hline Semiconductors & 8.87 & 13.25 & 10.63 & 0.25 & 1.64 & 4.47 \\
\hline Electronics \& Parts & 3.91 & 5.11 & 5.08 & 3.85 & 7.33 & 6.10 \\
\hline IT Equipment & 12.56 & 14.89 & 17.15 & 5.90 & 13.59 & 25.85 \\
\hline Home Appliances & 1.46 & 1.51 & 1.13 & 0.89 & 1.57 & 2.04 \\
\hline Automobiles & 5.62 & 9.34 & 14.93 & 0.71 & 1.31 & 2.85 \\
\hline Other Transport Equipment & 5.91 & 5.77 & 7.76 & 1.68 & 1.91 & 1.97 \\
\hline Precision Instruments & 1.29 & 2.64 & 6.25 & 2.62 & 2.95 & 3.11 \\
\hline Other Manufacturing & 3.43 & 1.73 & 0.78 & 9.40 & 10.37 & 6.88 \\
\hline
\end{tabular}

Source: UNCTAD (1992-2006)

While there are some differences between the two countries, it is common that the share of food \& beverage, and textiles \& clothes decreased rapidly. On the other hand, increases of export shares for certain industries including general machinery, semiconductors, electronics \& parts and IT equipment are prominent. This indicates the possibility that the two countries' concentration trends are converging, and competition will be severe in the world market for selected industries. It may work as incentives for the countries to attempt more rapid structural adjustment and create competitive edges. 


\subsection{Revealed comparative advantage}

The comparative advantage that firms or industries can acquire originates in various ways. Lafay (1992) categorizes the origins of comparative advantage as: favorable natural resource endowment of the territory concerned; lower relative costs through the choice of segments that are best suited to the macroeconomic factors of production; lower relative costs through innovation at microeconomic level in the production process, and; the acquisition of monopoly elements through the microeconomic creation of new products.

This concept of comparative advantage is often confused with competitiveness, however, there is a clear distinction. The two essential differences between the two concepts are, according to Lafay (1992):

i) Whereas competitiveness is measured between countries, for a given product, comparative advantage is measured between products for a given country; and

ii) Whereas competitiveness is subject to changes in the macroeconomic situation, comparative advantage is structural in nature.

As it is impossible to measure comparative advantage, which can be defined in autarky in a very strict sense, there have been efforts to find comparative advantage revealed through economic activities, in particular, from transaction of commodities between countries. While one of the most significant contributions for these revealed comparative advantage (RCA) was proposed by Balassa $(1963,1979)^{2}$, it has been widely criticized that most indexes, including Balassa's, distorted the real figures of comparative advantage as they ignore domestic consumption and production (and therefore, trade balance), and take into account the flow of relevant commodity only (for example, see Ballance, Forstner and Murray, 1987; Webster 1991). In this regard, RCA index proposed by CEPII (Lafay, 1992), which adopted a weighted indicator to reflect the contribution of trade balance and each product's importance for the country's total trade, is recognized as a better index. This index $f_{i k}$ for industry $\mathrm{k}$ in country $\mathrm{i}$ (hereafter a weighted RCA index or CEPII RCA index) is defined as

$$
f_{i k}=y_{i k}-z_{i k}
$$

where $\mathrm{y}_{\mathrm{ik}}$ is balance in relation to $\operatorname{GDP}\left(=1000 \times\left(X_{i k}-M_{i k}\right) / Y \quad\right)$ and $\mathrm{z}_{\mathrm{ik}}$ is attributed balance to industry $\left.\mathrm{k}\left(=\frac{X_{i k}+M_{i k}}{\sum\left(X_{i k}+M_{i k}\right)} \cdot y_{i k}\right)\right)^{3}$ In other words, this weighted RCA index for a specific industry is obtained by correcting the conventional RCA utilizing relative balance and the attribution of the balance to the industry. Rewriting this index gives

${ }^{2} \mathrm{KDI}$ (2003) presents RCA indexes for the Korean industries using the Balassa methods.

${ }^{3} Y$ is GDP, $X$ is exports and $M$ is imports 


$$
f_{i k}=\frac{1000}{Y_{i}} \cdot \frac{2\left(X_{i k} M_{i .}-X_{i .} M_{i k}\right)}{X_{i .}+M_{i .}}
$$

where the subscript . stands for the flow of commodities to a reference zone (such as the world). The RCA status of an industry can be classified as:

Country $\mathrm{i}$ has RCA in industry $\mathrm{k}$ iff fik $>0$,

Country i has RCD4 in industryk iff fik $<0$,

Country $\mathrm{i}$ has neither RCA nor RCD in industry $\mathrm{k}$ iff fik $=0$.

Different from most RCA indexes, the absolute value of $\mathrm{f}_{\mathrm{ik}}$ above can be larger than one. Table 3 and Figure 2-1 to 2-3 summarize the weighted RCA indexes for Korean and Chinese industries for the period from 1992 to 2005 . These figures provide striking results. The general trends of the indexes for Korea in the table and figure show that, in spite of relatively large fluctuations in the indexes for some industries, only petroleum \& coal industry moved from the range of revealed comparative disadvantage (RCD) to RCA over the period (though RCA index in 2005 is very close to zero), and semiconductor industry is the only one that changed its position from RCA to RCD. As of 1999, IT equipment, automobile and textile \& clothes industries maintained a strong RCA: the indexes for IT equipment and automobile industries increased and that for the textile \& clothing industry decreased dramatically, but remained positive. Overall, in 2005, Korea maintained RCA for seven industries - petroleum \& coal, textile \& clothes, home appliance, IT equipment, metal products, automobiles and other transport equipment industries. It is worth noting that the semiconductor industry, which has been regarded as one of the most important exporting sectors of Korea, recorded a very high level of RCA in 1992 and then lost its revealed comparative advantage. In 1999, the industry recorded slight RCD (-0.03) for the first time in the 1990s, and the degree of disadvantage became deeper since then recording -13.8 in 2005.

${ }^{4} \mathrm{RCD}$ stands for revealed comparative disadvantage. 
Table 3

CEPII RCA Indices to Korea and China (selected years)

\begin{tabular}{|c|c|c|c|c|c|c|}
\hline & \multicolumn{3}{|c|}{ Korea } & \multicolumn{3}{|c|}{ China } \\
\hline & 1992 & 1999 & 2005 & 1992 & 1999 & 2005 \\
\hline Food \& Beverage & -10.18 & -12.04 & -6.62 & 12.15 & 3.71 & 1.00 \\
\hline Textiles \& Clothes & 47.87 & 25.85 & 1.48 & 41.55 & 35.20 & 52.02 \\
\hline Paper Products, Printing, Publishing & -2.92 & -0.58 & -2.55 & -3.58 & -5.32 & -3.47 \\
\hline Chemical Products & -4.35 & -3.35 & -12.30 & -16.10 & -16.83 & -29.40 \\
\hline Petroleum \& Coal Products & -37.18 & -43.37 & 0.08 & 1.96 & -4.94 & 0.91 \\
\hline Non-metallic Mineral Products & -4.56 & -3.66 & -4.70 & 1.54 & 0.69 & 3.56 \\
\hline Basic Metals & -3.31 & -10.26 & -17.60 & -11.46 & -8.36 & -12.21 \\
\hline Metals & 2.16 & 0.19 & 0.36 & 2.04 & 2.22 & 7.36 \\
\hline General Machinery & -26.87 & -10.47 & -13.48 & -24.71 & -15.67 & -17.90 \\
\hline Semiconductors & 5.71 & -0.03 & -13.78 & -1.93 & -8.47 & -54.27 \\
\hline Electronics \& Parts & -0.99 & -2.84 & -12.61 & -3.07 & -2.67 & -2.11 \\
\hline IT Equipment & 20.16 & 24.02 & 37.90 & 0.23 & 5.56 & 49.02 \\
\hline Home Appliances & 3.07 & 3.94 & 2.68 & 1.10 & 2.59 & 5.83 \\
\hline Automobiles & 10.61 & 24.29 & 37.76 & -5.90 & 0.03 & -0.28 \\
\hline Other Transport Equipment & 5.53 & 13.38 & 16.27 & -2.90 & -0.80 & 0.31 \\
\hline Precision Instruments & -5.33 & -4.18 & -9.21 & -1.60 & -0.65 & -19.90 \\
\hline
\end{tabular}

Source: UNCTAD (1992-2006)

Different from its share in China's total exports, the Chinese economy still held a very strong RCA in textile \& clothing in 2005: In fact the strongest RCA is found in this industry. This is analogous to the sector's TSI, which has become larger over time. This finding indicates that, while the export share itself decreased, this industry's relative strength compared to the entire structure of trade has been strengthening. Another notable transformation is found from IT equipment industry: The industry's RCA improved from 0.23 in 1992 to 49.02 in 2005, being the second highest RCA next to textile \& clothes. In contrast, semiconductor industry in 2005 recorded extreme RCD, 54.27 , which was substantially lower than -1.93 in 1992 . The chemical products industry and 
general machinery industry also show strong RCD.

The average RCA and RCD of the Korean industries in the selected three years as in Table 3 are compared to those of China in Figures 2-1 to 2-3. ${ }^{5}$ As shown in Table 3, both Korea and China have RCA in seven industries respectively in 1992. The two economies shared RCA for four industries such as textile \& clothing, IT equipment, metal products, and home appliances. In addition to these four industries, Korea had RCA for semiconductors, automobiles and other transport industries. In contrast, China had RCA for food \& beverage, petroleum \& coal, and nonmetallic mineral products. Neither country had RCA against the world for such industries as basic metals, paper, printing \& publishing, chemical products, general machinery, precision machinery, and electronics \& parts. More findings from RCA analysis are summarized as follows ${ }^{6}$ :

The number of industries that the two economies share RCA has been increasing from four to five and then six in 1992, 1999 and 2005, respectively. While textile \& clothing, metal products, and IT equipment remained in this category, automobile industry was added in 1999. In 2005, China has lost RCA in automobiles ${ }^{7}$, however, the petroleum \& coal industry and other transport industries were newly added. While Korea also had RCA for the petroleum \& coal industry in 2005, the RCA index in that year was negligible (0.08).

While the RCA indices themselves changed, the signs did not change significantly in Korea. Korea always had RCA in seven industries; the only changes are (a) it has lost RCA in the semiconductor industry, and (b) it has gained RCA in petroleum \& coal products, though the index is very low as indicated. As of 2005, six industries out of seven in which Korea had RCA overlapped with those of China's RCA. Among these, RCA of Korea in IT equipment and other transport industries are getting stronger. In the case of China, metal products, IT equipment, home appliances and other transport equipment industries significantly improved their RCA. Even for the automobile industry that only Korea has RCA, China gradually increased its RCA. This means that the direction of industrial development for the two countries will be similar.

\footnotetext{
${ }^{5}$ Weighted RCA indices for the entire period are available from the authors on request. KDI (2003) contains Balassa's RCA indexes for the industries.

${ }^{6}$ Shaded areas in the figures indicate that the industry in the shade changed its comparative advantage positions over time.

${ }^{7}$ In fact, RCA index for the automobile industry in China in 1999 is only 0.03 .
} 
Basic Metal Products; Paper Products, Printing, Publishing;

Chemical Products; General Machinery; Precision Machinery;

Electronics \& Parts

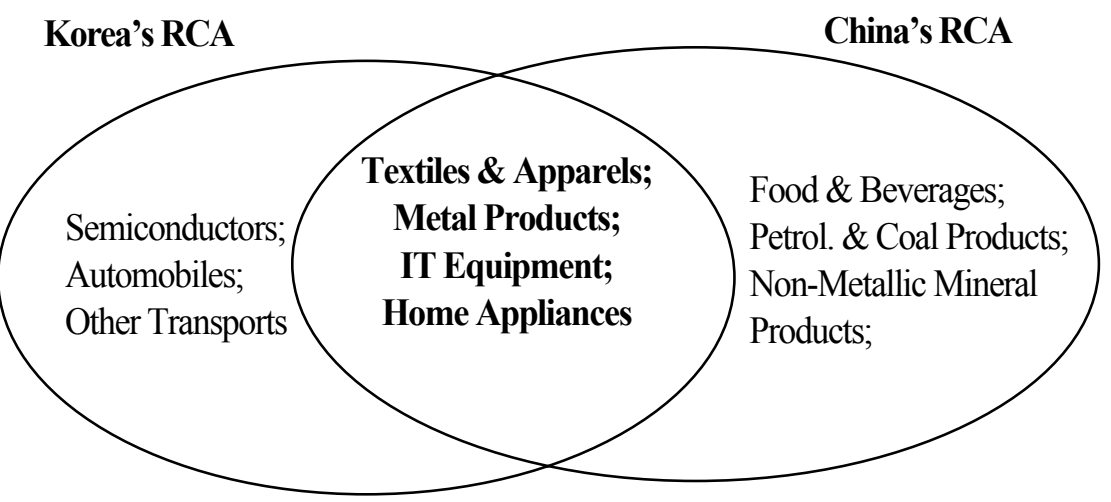

Figure 3. RCA and RCD for Korea and China (1992)

Basic Metal Products; Paper Products, Printing, Publishing;

Chemical Products; General Machinery; Precision Machinery; Electronics \& Parts; Petrol. \& Coal Products;

Korea's RCA China's RCA

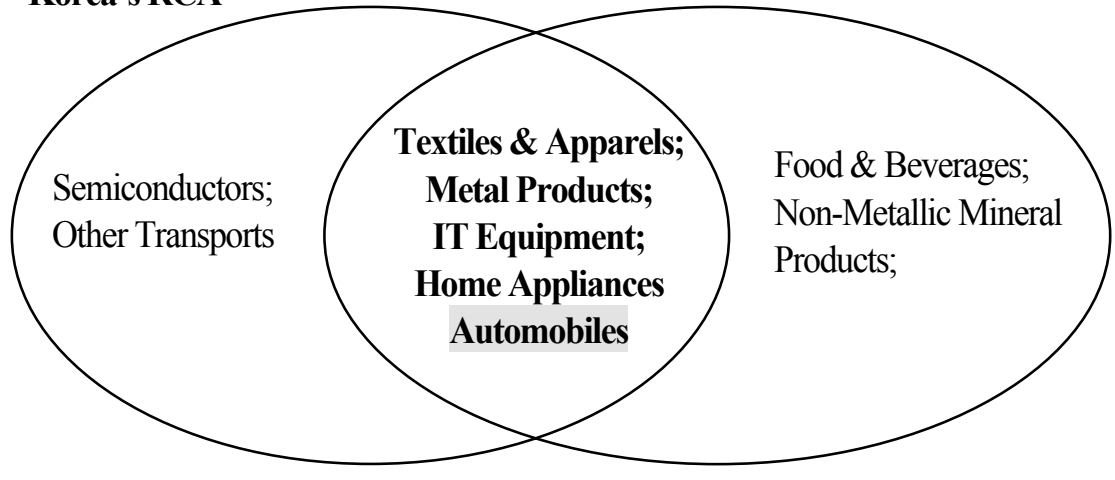

Figure 4. RCA and RCD for Korea and China (1999) 


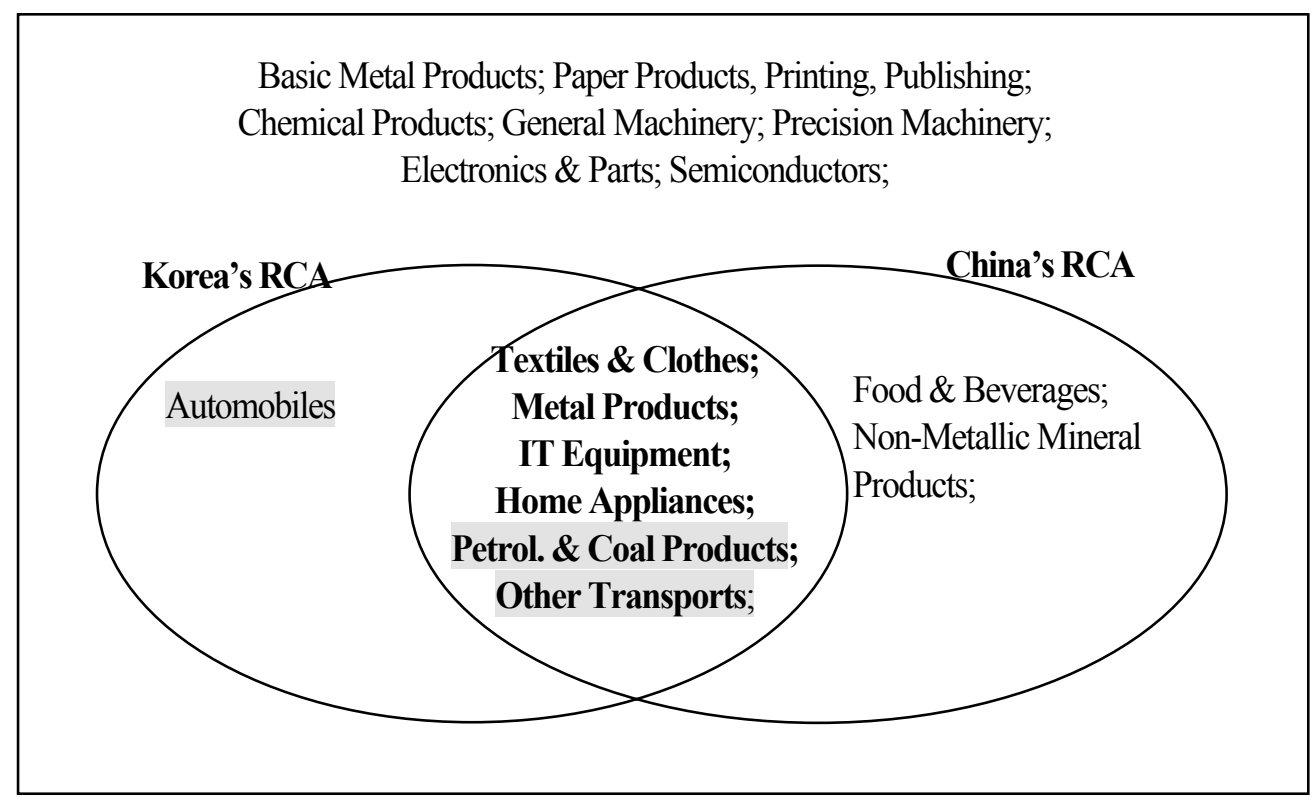

Figure 5. RCA and RCD for Korea and China (2005)

\section{Determinants of Korea's market shares - the China effect}

\subsection{Data}

This section investigates the impact of China's penetration into certain markets on the export performance of Korea in the same market. Data collected for analysis are summarized in Table 4. As data from different sources use different classification system, they were matched based on the KDI system. All the nominal values were converted into real valves using 2000 as a base year.

Table 4

Data Sources

\begin{tabular}{l|c|c|l|c}
\hline \multicolumn{2}{c|}{ Source } & Classification & \multicolumn{2}{c}{ Description } \\
Effective \\
\hline \hline
\end{tabular}




\begin{tabular}{l|c|c|l|c}
\hline $\begin{array}{l}\text { World } \\
\text { Development } \\
\text { Indicator }\end{array}$ & $\begin{array}{l}\text { World } \\
\text { Bank }\end{array}$ & Country & GDP, Growth Rate of GDP, etc & To 2005 \\
\hline $\begin{array}{l}\text { Rearranged } \\
\text { from KDI }\end{array}$ & $\begin{array}{c}\text { KDI } \\
\text { Sureau of } \\
\text { Stat. }\end{array}$ & $\begin{array}{c}\text { Korea } \\
\text { Industry }\end{array}$ & $\begin{array}{l}\text { Real Exchange Rate, } \\
\text { Real Effective Exchange Rate, } \\
\text { Industry's output }\end{array}$ & To 2006 \\
\hline $\begin{array}{l}\text { Korea Trade } \\
\text { Statistics }\end{array}$ & KITA & $\begin{array}{l}\text { Country \& } \\
\text { HSK Code }\end{array}$ & Exports and Imports & To 2006 \\
\hline
\end{tabular}

\subsection{Model}

In this section, the interest is focused on the determinants of Korea's market share for each industry, particularly the expansion of China's market share. It is assumed that industry's total product, market size, exchange rates and export performance of China measured by its market share affect the market share of Korea. The data for 16 manufacturing industries following KDI classification, for six export markets - the US, China, Japan, ASEAN, EU and the world - was used for 14 years from 1992 to 2005 . The basic functional form is

$$
X_{i j t}=F\left(Z_{i j t}, S_{i j t}\right)+u_{i j t}
$$

$X$ is the market share of Korea, $Z$ is a vector of independent variables, $S$ is the market share of China, and subscripts $i, j$ and t respectively stand for industry, region (market) and time. The market share is used instead of total value of exports, as the latter does not reflect the export performance properly. For example, when a certain market rapidly expands, it may be the case that Korea's total export to the market increases while the market share decreases. In this case, it would be improper to conclude that Korea's export performance is successful simply because it expands its absolute size of exports to the market. It would be more proper to evaluate that the export performance is successful when its market share increases or the growth rate of exports increases faster than the growth rate of expansion of the market size. Accordingly, when the effect of China is investigated, market shares should be focused rather than total value of exports. Other independent variables which are assumed to affect the market share of Korean industries include the size of industries, the size of the market and exchange rates. Consequently, the estimation for each industry is based on the following equation:

$$
\log \mathrm{XS} \mathrm{K}_{\mathrm{jt}}=\beta_{0}+\beta_{1} \log \mathrm{ISK}_{\mathrm{t}}+\beta_{2} \log \mathrm{MS}_{\mathrm{jt}}+\beta_{3} \log \mathrm{XSC}_{\mathrm{jt}}+\beta_{4} \log \mathrm{ER} \mathrm{K}_{\mathrm{jt}}+\mathrm{u}
$$

As the market size is difficult to measure, GDP of the economy (nation or region) is used. The 
seemingly unrelated regression (SUR) method is used to estimate the above equation. The market share of Korea in each region for each industry would be influenced by certain variables which were not directly included in the equation (such as FTA between some economies), and consequently the residuals might be correlated to one another. ${ }^{8}$ Accordingly, the contemporaneous correlation between cross sections and heteroscedasticity are allowed. As there are only 14 yearly observations, the stationarity of variables were not considered as advised by Enders (1998). However, it is suspected that the error term has a first-order autoregressive error structure such as $u_{i j t}=\varphi_{i j} u_{i j t-1}+\varepsilon_{i j t}$. The Durbin-Watson statistics for the datasets used here, from initial estimation, suggested the possibility of autocorrelation and therefore, first order autocorrelation is also allowed.

When we denote cross-section observations by subscript $h(h=1,2,3, \ldots, H)$ and time series observations by $t(t=1,2,3, \ldots, T)$, the contemporaneous correlation between cross sections and heteroscedasticity are presented as $E\left(u_{h t} u_{k t}\right)=\sigma_{h k}^{2}$ and $E\left(u_{h t}^{2}\right)=\sigma_{h h}^{2}$. We also impose the following assumptions for the error disturbance term: $E\left(\varepsilon_{h t}\right)=0, E\left(u_{h, t-1} \varepsilon_{h t}\right)=0, E\left(\varepsilon_{h t} \varepsilon_{k t}\right)=\phi_{h k}$ $E\left(\varepsilon_{h t} \varepsilon_{k s}\right)=0($ for $\mathrm{s} \neq \mathrm{t})$, and $E\left(u_{h t} u_{k t}\right)=\sigma_{h k}^{2}=\phi_{h k} /\left(1-\varphi_{h} \varphi_{k}\right)$.

With these assumptions on the error structure and components, the covariance matrix for the vector of random errors $\underline{u}$ can be expressed as:

$$
\begin{gathered}
E\left(u u^{\prime}\right)=V=\left[\begin{array}{cccc}
\sigma_{11}^{2} \underline{\Omega}_{11} & \sigma_{12}^{2} \underline{\Omega}_{12} & \cdots & \sigma_{1 H}^{2} \underline{\Omega}_{1 H} \\
\sigma_{21}^{2} \underline{\Omega}_{21} & \sigma_{22}^{2} \underline{\Omega}_{22} & \cdots & \sigma_{2 N}^{2} \underline{\Omega}_{2 H} \\
\vdots & \vdots & \ddots & \vdots \\
\sigma_{H 1}^{2} \underline{\Omega}_{H 1} & \sigma_{H 2}^{2} \underline{\Omega}_{H 2} & \cdots & \sigma_{H H}^{2} \underline{\Omega}_{H H}
\end{array}\right] \\
\underline{\Omega}_{h k}=\left[\begin{array}{cccc}
1 & \varphi_{k} & \cdots & \varphi_{k}^{T-1} \\
\varphi_{h} & 1 & \cdots & \varphi_{k}^{T-2} \\
\vdots & \vdots & \ddots & \vdots \\
\varphi_{h}^{T-1} & \varphi_{h}^{T-2} & \cdots & 1
\end{array}\right] .
\end{gathered}
$$

The matrix V is estimated by a two-stage procedure, and the parameters in equation (3) are then estimated using the general linear squared (GLS) method, as suggested by Parks(1967). A consistent estimator of the first-order autoregressive parameter is then obtained as follows:

\footnotetext{
${ }^{8}$ The SUR estimation method will increase efficiency of the estimator if the errors of different equations in the system to be estimated are contemporaneously correlated. We can test for contemporaneous correlation using a simple LM test constructed as follow:

$\lambda=T \sum r_{i j}^{2}$, where $\gamma_{i j}^{2}$ is the squared correlation of the estimator of the variance obtained using OLS on each equation of the system. This test is distributed as $\chi 2(\mathrm{n})$, where $\mathrm{n}$ is the number of squared correlations term. For all the system estimated, the test statistic of no contemporaneous correlation is rejected at less than $1 \%$ significance level justifying the use of the SUR estimation. Furthermore, it is well known that if the error is not subject to contemporaneous correlation, SUR will be equivalent to standard GLS estimation

${ }^{9}$ When autocorrelation is not considered, the matrix $\underline{\Omega}_{h k}$ reduces to identity matrix $\mathrm{I}_{\mathrm{T}}$, and $\mathrm{V}=\Sigma \otimes I_{T}$, where $\Sigma$ is a variance-covariance matrix of $\sigma_{h k}$.
} 


$$
\hat{\varphi}_{h}=\left(\sum_{t=2}^{T} \hat{u}_{h t} \hat{u}_{h, t-1}\right) /\left(\sum_{t=2}^{T} \hat{u}_{h, t-1}^{2}\right) \text {, where } \mathrm{h}=1,2, \ldots, \mathrm{H} .
$$

\subsection{Results and implications}

While quantitative analyses were conducted for 16 industries including 'other manufacturing', Table 5 reports the results for coefficients estimated that show the effect of China's market share on Korea's market share. ${ }^{10}$ The coefficients for nine representative industries are presented in the table for simplicity, where these nine industries account for about $90 \%$ of total manufacturing exports of Korea in 2006.

Excluding the Chinese market where the effect of the US and Japan's market shares are considered, the table shows the effects of China's market share expansion for nine industries in five markets including the world. Out of these 45 cases, 21 cases show negative effects from China's market share. However, the effect also seems positive in nine cases, implying that Korean industries increased their market share as Chinese industries did. This is possible when products from both countries work as complementary, or somehow related. For example, when the market size grows, it is possible that both countries increase their market shares even when they are not complementary but substitutable. Or both countries' shares increase together as other countries' shares decrease. Finally, as industry classification is broad, there may be segmented markets for sub-level industries with unsubstitutible products. Changes in China's market share did not give any significant effect on the market share of the Korean industries in 15 cases.

Investigating the effects by economies, the negative effects from China's penetration are the most prominent in the US market. Except for the semiconductor industry, the coefficients for all Korean industries turn out to be negative, where in six cases, they are significant. This significant and negative effect becomes weaker in Japanese, ASEAN and EU markets, in that order: five, four and one industries/industry experienced reduction of market share(s) due to the expansion of China's market share. As a result, while the China effect is the strongest in the US market, it is not clearly found in the EU market: Korea suffered from China's expansion in EU in the IT equipment industry only, where the significance is only marginal. For other cases, Korean industries were either unaffected by China's expansion, or actually raised their market shares.

\footnotetext{
${ }^{10}$ More results for other variables are available on requests from the authors.
} 
Table 5

Export Performance of Korea and China Effects - Summary

\begin{tabular}{|c|c|c|c|c|c|c|c|}
\hline & US & CHINA & JAPAN & ASEAN & EU & WORLD & $(-,+, 0)$ \\
\hline \multirow[t]{2}{*}{$\begin{array}{l}\text { Textile } \quad \& \\
\text { clothing }\end{array}$} & $-0.858^{*}$ & -0.833 & $-2.579^{* * *}$ & -0.382 & -0.778 & $-0.005^{* *}$ & $(3,0,3)$ \\
\hline & $(-1.75)$ & $(-0.93)$ & $(-4.89)$ & $(-1.74)$ & $(-1.47)$ & $(-0.04)$ & \\
\hline \multirow{2}{*}{$\begin{array}{l}\text { Chemical } \\
\text { products }\end{array}$} & -0.197 & $-1.029^{* * *}$ & $0.319^{* * *}$ & $0.320^{* * * *}$ & 0.122 & $-0.126^{*}$ & $(2,2,2)$ \\
\hline & $(-1.1)$ & $(-3.07)$ & $(4.22)$ & (12.48) & $(1.17)$ & $(-1.82)$ & \\
\hline \multirow[t]{2}{*}{$\begin{array}{l}\text { General } \\
\text { machinery }\end{array}$} & $-0.285^{* * *}$ & 0.403 & 0.093 & $-0.204^{* * *}$ & -0.093 & -0.009 & $(2,0,4)$ \\
\hline & $(-4.11)$ & (1.3) & $(1.27)$ & $(-3.76)$ & $(-0.42)$ & $(-0.39)$ & \\
\hline \multirow[t]{2}{*}{ Semiconductors } & $0.224^{* * *}$ & 0.097 & -0.057 & $-0.142^{* * *}$ & $0.149^{* * *}$ & $-0.510^{* * *}$ & $(2,2,2)$ \\
\hline & $(7.23)$ & $(0.23)$ & $(-0.94)$ & $(-3.66)$ & $(3.61)$ & $(-6.36)$ & \\
\hline \multirow[t]{2}{*}{$\begin{array}{l}\text { Electronics \& } \\
\text { parts }\end{array}$} & $-1.054^{* * *}$ & -0.383 & $-0.199^{* * *}$ & 0.996 & $0.444^{* * *}$ & -0.108 & $(2,1,3)$ \\
\hline & $(-14.47)$ & $(-0.50)$ & $(-3.78)$ & $(1.15)$ & $(3.3)$ & $(-1.18)$ & \\
\hline \multirow[t]{2}{*}{ IT equipment } & $-0.696^{* * *}$ & -1.155 & $-1.305^{* * *}$ & $-0.968^{*}$ & $-0.254^{*}$ & $-0.285^{* * *}$ & $(5,0,1)$ \\
\hline & $(-5.86)$ & $(-1.88)$ & $(-6.45)$ & $(-1.99)$ & $(-2.02)$ & $(-7.44)$ & \\
\hline \multirow[t]{2}{*}{ Automobiles } & -0.096 & $-1.470^{* * * *}$ & $0.166^{* * *}$ & $0.698^{* * *}$ & $0.182^{* * *}$ & -0.057 & $(1,3,2)$ \\
\hline & $(-0.68)$ & $(-4.49)$ & $(4.98)$ & $(4.01)$ & (13.48) & $(-0.82)$ & \\
\hline \multirow[t]{2}{*}{ Other transports } & $-0.715^{* * *}$ & -1.311 & $-0.191^{*}$ & 0.070 & $0.663^{* * *}$ & $-0.210^{*}$ & $(3,1,2)$ \\
\hline & $(-7.48)$ & $(-1.33)$ & $(-1.99)$ & $(0.25)$ & $(3.00)$ & $(-1.89)$ & \\
\hline \multirow[t]{2}{*}{$\begin{array}{l}\text { Precision } \\
\text { instruments }\end{array}$} & $-0.538^{* * *}$ & 0.910 & $-1.707^{* *}$ & $-1.594^{* * *}$ & 0.376 & -0.903 & $(3,0,3)$ \\
\hline & $(-4.37)$ & $(1.22)$ & $(-2.11)$ & $(-17.59)$ & (1.03) & $(-1.2)$ & \\
\hline$(-,+, 0)$ & $(6,1,2)$ & $(2,0,7)$ & $(5,2,2)$ & $(4,2,3)$ & $(1,4,4)$ & $(5,0,4)$ & $\begin{array}{c}(23,9,2 \\
2)\end{array}$ \\
\hline
\end{tabular}

Note: The nine industries summarized in the table explain about $90 \%$ of Korea's total manufacturing exports in 2006. In the Chinese market, the effect of market penetration by two advanced countries, the US and Japan, was analyzed.

As indicated previously, RCA of Korea and China overlapped for selected industries over time. While some of these industries changed, the two nations always possessed RCA for selected industries such as textile \& clothes, IT equipment and home appliances. Table 5 shows that for the two industries, textile \& clothes and IT equipment, Korea's market shares are significantly affected by the changes in China's market share adversely. In other words, in the case of textile \& clothes, Korea's market shares in the US, Japan and the whole world were negatively affected by growth in China's market share. For IT equipment, this phenomenon is even more prevalent; virtually in all the important markets, Korea's market shares were significantly decreased by China's market expansion. Other transport equipment and precision instrument industries were also found to be frequently affected by China's penetration in major markets. 
Nevertheless, it is too premature to conclude that the challenges from China are all negative and harmful to Korea. This is so for at least three reasons. First, as Gaulier, Lemoine and UnalKesenci (2006) described, China has become an export plate-form for multinationals. Hyun (2006) also pointed out that China has been the most attractive destination of Korea's outbound FDI. Sometimes Using the fragmentation theory approach, Kimura (2007) confirmed that sophisticated production-process-wise division of labor was widely developed in East Asia, where both interand intra-firm trade actively evolved. Therefore, parts of China's exports could be explained by Korean firms in China, or Korea, exports capital and/or technology intensive parts to China and China combines them to export to the world. In fact, active transaction of parts and final goods between Korean firms in the two countries contributed ever increasing trade volume between them, of which growth rate has been considerably higher than that of Korea's exports to the world.

Second, severe competition could improve productivity of Korean firms, or help the Korean economy to accelerate its structural adjustment towards highly-elaborated or high-tech intensive industries. Lee (2007) found that the manufacturing sectors facing more intense competition improved productivity rapidly. ${ }^{11}$ Also, for Korea, the growth of China can be a valuable opportunity that the nation can more actively participate in international production chains, whose recent development was significantly contributed by the emergence of China (Gaulier, Lemoine and Unal-Kesenci, 2006).

Third, as mentioned earlier, while the analyses with 15 industries in this paper could provide a broad picture of the relationship between the two countries, it may miss more accurate and detailed aspects of trade progressed in disaggregated levels. This point was pointed out by some researchers, including Kimura (2007) and Kang (2006) ${ }^{12}$. For example, even when classified as the same industry, exports from Korea could be different from those from China in sub-classification level, by being differentiated vertically or horizontally.

In contrast, for the industries that Korea has maintained relatively strong edges such as automobiles, China's penetration significantly and negatively affected Korea's market shares in only limited cases. For automobiles, no major markets share was negatively affected by China. Kimura's (2007) view may be applied. He explained that for the automobile industry, service link cost (to provide products to consumers) is relatively high (higher than say electronics industry) compared to relocation (of production base) cost. Therefore, the relocation of production bases of electronics are more widely observed than that of automobiles. The only coefficient with significant negative sign is for the Chinese market, however, as discussed earlier, the effect of the market shares of the US and Japan were used when analyzing Korea's market share in China. Therefore, it indicates that Korean automobile industries were challenged by developed countries in the Chinese market.

For other industries for which the impact of China was relatively weak such as the chemical industry, general machinery and semiconductors, neither country has comparative advantage. In

\footnotetext{
${ }^{11}$ More accurately, Lee (2007) showed productivity improvement in various import-competing industries following the liberalization of domestic markets.

${ }^{12}$ While Kang (2006) provided implicative findings, his focus is mainly on the effect of Korea-China bilateral trade on the Korean economy.
} 
summary, while the China impact was minimal for the automobile industry, limited negative impacts were found for sectors that neither country has comparative advantage. Among the industries that both countries have comparative advantage, textile \& clothing and IT equipment industries received the strongest impact.

\section{Summary}

This study investigated the patterns of trade of Korea since 1992, and compared certain aspects with those of China, the largest trade partner of Korea. RCA indices were computed for each industry, and their movements over time were analyzed. The major findings in this study indicate the possibility of Heckscher-Ohlin Crowding Hypothesis (Leamer and Lunborg, 1995), which is well known as the "nut-cracking" effect in more popular terms. Heckscher-Ohlin Crowding Hypothesis explains the situation where one economy is caught up by late-comers and loses comparative advantage for the sectors that it conventionally maintained comparative advantage, of and at the same time, cannot construct strong comparative advantage for more advanced sectors. Choi, Tcha and Kim (2005) asserted that the technology gap between Korea and China has been narrowed, and if the trend were sustained, then China would catch up to Korea in a few years in various industries. In contrast, Kang (2006) argued that the structure of comparative advantage would be continued for the time being, as the industrial structure of Korea would rapidly advance towards high-tech intensive ones. Nevertheless, Kang (2006) also agreed that the catch-up process will be observed for industries at disaggregated levels, even when the striking changes in comparative advantage will not be found at an aggregated level.

This study confirms that in general, the competition between Korea and China was getting severe in the sectors where Korea traditionally possessed comparative advantage. For example, for all the industries that Korea had RCA in 2005, except automobile industries, China also obtained comparative advantage. In contrast, Korea failed to achieve RCA in new high-tech intensive industries such as electronics \& parts and precision instruments. The concern that Korea has not effectively coped with challenges from China was pointed out by many researchers, for example, Choi and Tcha (2005). They empirically found that the emergence of China accelerated the 'exit' of Korean firms in the industries facing competition from China, however, there was no evidence that these industries dealt with intensifying competition by increasing capital-labor ratio. It is critical for Korea to move towards more high-tech industries, or adopt advanced technology to create competitive edges. In this context, the challenges from China can be a critical opportunity for Korea to successfully carry out another structural transformation. Further, as pointed out in the previous section, it would be wise to actively participate in international production chains, and create more complementary relationship with foreign countries.

The effect of China is more rigorously reviewed by quantitative analyses. For 9 major industries in 5 major markets, 21 cases show negative effects from China's market share. In other words, in 21 cases out of 45 cases, Korean industries experienced contraction in market shares by the expansion of China's market share. However, the effect also seems positive in nine cases, 
meaning that Korean industries increased their market share as Chinese industries did. While this result may not be intuitive at first glance, it should be considered that the classification in this study is rather broad; we have 16 industries for the entire manufacturing sector. Also, it is possible that in some industry's market, the exports from Korea and China could be complementary rather than substitutable; or they could be independent in sub-classification. The result of this study also shows that changes in China's market share did not give any significant impact on the market share of the Korean industries in 15 cases.

The negative effects from the expansion of China's market share are the most prominent in the US market. Except for the semiconductor industry, the coefficients for all Korean industries turn out to be negative; in six major industries, they are significant. This significant and negative effect becomes weaker in Japanese, ASEAN and EU markets, in the given order: five, four and one Korean industries/industry in these markets experienced reduction of market share(s) due to the expansion of China's market share. This implies that Korea could achieve a relatively large benefit from completing FTA talks with the US, where the adverse impacts from China were the most significant. The China effect is not clearly found in the EU market: Korea suffered from China's expansion in EU in the IT equipment industry only, where the significance is only marginal. For the other cases, Korean industries were either unaffected by China's expansion, or actually raised their market shares.

If we investigate the China effect from different angles, say by industry, Korea's market shares are significantly affected by the changes in China's market share adversely in textile \& clothes and IT equipment. This finding is eminent, in particular, for IT equipment; in all the major markets, Korea's market shares in IT equipment were significantly decreased by China's market expansion. In contrast, for the industries that Korea has maintained relatively strong edges compared to China, such as automobiles, China's penetration did not significantly and negatively affect Korea's market shares. For automobiles, virtually no major market's share was negatively affected by China. Nevertheless, it was also found that market share of the Korean automobile industry in China was, in general, negatively affected by developed countries' penetration.

\section{Acknowledgements}

Authors thank to KDI fellows who gave constructive comments to the earlier version of this paper. Authors are also grateful to two anonymous referees for their valuable comments. Research assistance from Daeyong Kim and editorial assistance from Nan-Hee Kim are gratefully acknowledged 


\section{References}

Ballance, R., H. Forstner and T. Murray. 1987. Consistency tests of alternative measures of comparative advantage. Review of Economics and Statistics. (February): 157-161.

Balassa, B. 1963. An empirical demonstration of classical comparative cost theory. Review of Economics and Statistics. (August): 231-238. 1979. The changing pattern of comparative advantage in manufactured goods. Review of Economics and Statistics. (May): 259-265.

Choi, Y. and Tcha, M. 2005. The China effect on entry and exit of firms in Korea. In J. Kim ed. The role of SMEs in Transforming towards the Innovation-oriented Economy. Research Monograph 2005-05: 71-108. Seoul: KDI. , and J. Kim. 2005. The Impact of Economic Growth and Trade Expansion of China on the Korean Economy. Research Monograph 2005-04. Seoul: KDI.

Gaulier, G., F. Lemoine and D. Unal-Kesenci. 2006. China's emergence and the reorganiszation of trade flows in Asia. CEPII Working Paper No. 2006-05. CEPII.

Hyun, J. T. 2006. The structural changes in the Korean economy and agenda for future development. paper presented to the Conference for Korean Economic Association. Seoul.

Kang, D. 2006. The effects of the emergence of China to the growth of the Korean industries. Monograph, Seoul: KIET.

Kim, I. 2001. Korea's growth potential and crisis management. In I. Kim, S. Kwack and S. Park eds. Growth, Productivity and Vision for the Korean Economy. Seoul: Pakyoungsa.

Kimura, F. 2007. The mechanics of production networks in Southeast Asia: the fragmentation theory approach. Center for Economic Institutions Working Paper Series No.2007-8, CEI.

Ko, I., B. Cho, J. Lee, J. Lee and H. Lee. 2003. Analysis of division of production in East Asia and its implications for the regional FTA. Collaborated Research Series 03-03. Seoul: KDI.

Korea Development Institute (Knowledge Based Economy Team). 2003. A Study on the Competitiveness of the Korean Industries. Research Monograph 2003-07. Seoul: KDI.

Kwack, S. 2001. Factors contributing to the financial crisis in Korea. In I. Kim, S. Kwack and S. Park eds. Growth, Productivity and Vision for the Korean Economy. Seoul: Pakyoungsa.

Lafay, G. 1992. The measurement of revealed comparative advantages. In M. Dagenais and P. Muet eds. International trade modeling. London: Chapman \& Hall.

Leamer, E. and P. Lundborg. 1995. A Heckscher-Ohlin view of Sweden competing in the global market. NBER Working Paper No. 5114. NBER.

Lee, S. 2007. The effect of market liberalization on plant productivity. In M. Tcha ed. The Korean economy in the era of globalization. Research monograph 2007-01: 92-134. Seoul: KDI.

Parks, R. 1967. Efficient estimation of a system of regression equations when disturbances are both 
serially and contemporaneously correlated. Journal of the American Statistical Association. (62): 500 509.

Tcha, M. 2004. Changing patterns in production and trade in Korea - Findings and implications. In J. Suh ed. Industrial Dynamism and Competitiveness in the East Asian Economies. Seoul: KDI.

and M. Lee. 2003. The Koran economy: triumphs, difficulties, and triumphs again?. In M. Tcha and C. Suh eds. The Korean Economy at the Crossroads. London: Routledge.

Webster, A. 1991. Some issues in the measurement of comparative advantage. Applied Economics. (23): 937-948. 